\title{
EFFECT OF SODIUM CHLORIDE ON GENTAMICIN ACCUMULATION BY ESCHERICHIA COLI: CORRELATION WITH BACTERIAL GROWTH AND VIABILITY
}

\author{
Allen H. Heller*, Reynold Spector and Molly Aalyson \\ Department of Pharmacology, Harvard Medical School, Boston, Massachusetts 02115, \\ and Departments of Medicine and Pharmacology, University of Iowa, \\ Iowa City, Iowa 52242, U.S.A. \\ (Received for publication February 18, 1980)
}

\begin{abstract}
The kinetics of gentamicin accumulation by a sensitive strain of Escherichia coli were investigated at gentamicin concentrations from 0.02 to $200 \mu \mathrm{g} / \mathrm{ml}$. Accumulation with time shows two energy-dependent phases and is saturable. Sodium chloride delays the onset of the second more rapid energy-dependent phase and decreases the magnitude of gentamicin accumulation for incubations up to 60 minutes at all gentamicin concentrations tested. Simultaneous determinations of accumulation, cell viability, and growth inhibition indicate that antimicrobial activity is correlated with the magnitude of gentamicin accumulation. These observations suggest that altered bacterial accumulation of gentamicin explains the effect of sodium chloride on the antimicrobial activity of gentamicin.
\end{abstract}

The aminoglycoside antibiotics streptomycin and gentamicin are accumulated by Gram-negative bacteria by an energy-dependent process ${ }^{3,5)}$. BRYAN and co-workers have described three phases of accumulation. The first phase represents rapid ionic binding to cell surface components and is not energydependent ${ }^{3,5)}$. A significantly greater proportion of first phase uptake is removed by washing with $3 \%(\mathrm{w} / \mathrm{v}) \mathrm{NaCl}$ as compared to water ${ }^{3)}$. Further accumulation is dependent on a source of aerobically generated energy. The first energy-dependent phase (EDP-1) is underway before any changes in cellular permeability or inhibition of protein synthesis. EDP-1 varies in duration and rate depending on the gentamicin concentration ${ }^{3)}$. The second energy-dependent phase (EDP-2) is more rapid than EDP-1 and requires ribosomal binding. The onset of this phase corresponds with the onset of the inhibition of protein synthesis and loss of cell viability ${ }^{3,5}$.

Divalent and monovalent cations antagonize gentamicin transport across the cell membrane ${ }^{5}$. BEGGS and ANDREWs ${ }^{1)}$ found that cations inhibit dihydrostreptomycin accumulation by Mycobacterium smegmatis and correlated this effect with the inhibition of antimicrobial activity ${ }^{2}$. We studied the effect of sodium chloride on the kinetics of gentamicin accumulation by $E$. coli and its relationship to antimicrobial activity.

\section{Materials and Methods}

Bacterial strain

E. coli K12 W3101 sensitive to gentamicin was obtained from Dr. Thomas O'Brien, Dept. of Medicine, Harvard Medical School.

Test medium

Nutrient Broth (obtained from Baltimore Biological Laboratories) was used throughout. The

* Present address and all correspondence should be sent: Department of Neurology, Children's Hospital Medical Center, 300 Longwood Avenue, Boston, MA 02115, U.S.A. 
unadjusted cation concentrations were as follows: $\mathrm{Na} 15 \mathrm{~mm}, \mathrm{Ca} 0.4 \mathrm{~mm}$, and $\mathrm{Mg} 0.082 \mathrm{~mm}$. The $\mathrm{pH}$ was $6.9 \pm 0.1$.

Radiochemicals

${ }^{3} \mathrm{H}-$ Gentamicin sulfate (specific activity $711 \mathrm{mCi} / \mathrm{g}$ ) purified by column chromatography was obtained from Amersham Corporation. ${ }^{14} \mathrm{C}$-Inulin $(2.94 \mathrm{mCi} / \mathrm{g}$ ) was obtained from New England Nuclear Corp. Purified unlabeled gentamicin sulfate was a gift from the Schering Corp.

Gentamicin accumulation

An inoculum of $2 \sim 4 \mathrm{ml}$ of an overnight culture in nutrient broth was added to $100 \mathrm{ml}$ of the test medium in $250 \mathrm{ml}$ flasks. Flasks were pre-incubated in a Dubnoff metabolic shaker at $37^{\circ} \mathrm{C}$ (or $4^{\circ} \mathrm{C}$ ) at "speed setting 4" to establish logarithmic growth and the optical density at $600 \mathrm{~nm}\left(\mathrm{OD}_{600}\right)$ was monitored. At $\mathrm{OD}_{600} \sim 0.06$ ("early log phase") or $\mathrm{OD}_{600} \sim 0.250$ ("log phase"), ${ }^{3} \mathrm{H}$-gentamicin sulfate was added to the desired final concentration $(0.02 \sim 200 \mu \mathrm{g} / \mathrm{ml})$. At various intervals $5 \mathrm{ml}$ of the cell culture were filtered through polycarbonate membrane filters, $0.4 \mu \mathrm{m}$ (Nucleopore Corp., Pleasanton, Calif.). Filters were washed twice with $8 \mathrm{ml}$ of $3 \% \mathrm{NaCl}$ to minimize ionic gentamicin binding at the cell surface ${ }^{3,4}$, and placed in sterile test tubes containing $2 \mathrm{ml}$ of distilled water. Test tubes were shaken for 1 minute with a vortex mixer to remove bacteria, and aliquots of this $2 \mathrm{ml}$ wash (filter wash) were removed for protein determination by the LowRY method ${ }^{10)}$ and for assay of ${ }^{3} \mathrm{H}-$ gentamicin. To measure non-specific binding of ${ }^{3} \mathrm{H}$-gentamicin to the filters, medium containing labeled gentamicin but not bacteria was also filtered, and aliquots of the $2 \mathrm{ml}$ filter wash were assayed for ${ }^{3} \mathrm{H}$-gentamicin. Counts due to non-specific binding to the filters were less than twice the counts obtained from assay of distilled water (background). The gentamicin radioactivity which remained associated with the filters was less than $5 \%$ of the total gentamicin radioactivity in the filter wash for all accumulation values reported. The ${ }^{3} \mathrm{H}$ radioactivity in the filter wash and incubation medium was assayed with $10 \mathrm{ml}$ Scintiverse, using a Packard Tri-Carb 3375 liquid scintillation counter. Gentamicin content was expressed as $\mu \mathrm{g}$ gentamicin sulfate per $\mathrm{mg}$ of bacterial protein.

In some cases results of accumulation studies were confirmed by a centrifugation method. Bacteria were incubated as described above. During incubation ${ }^{14} \mathrm{C}$-inulin was added at concentration $0.272 \mu \mathrm{g} /$ $\mathrm{ml}$. The tubes were centrifuged for 5 minutes at $48,000 \mathrm{~g}\left(4^{\circ} \mathrm{C}\right)$. The pellet was not washed. The pellet was assayed for ${ }^{3} \mathrm{H}$-gentamicin and ${ }^{14} \mathrm{C}$-inulin by double isotope counting ${ }^{9)}$, and for protein by the LOWRY method ${ }^{10)}$. The ${ }^{3} \mathrm{H}$-gentamicin and protein content present in the medium residue was calculated from the ${ }^{14} \mathrm{C}$-inulin activity associated with the pellet.

Growth curves

A Beckman spectrophotometer was used to follow bacterial growth at $\mathrm{OD}_{000}$ in the absence and presence of gentamicin. Optical density was determined using $3 \mathrm{ml}$ glass cuvettes containing aliquots of the cell culture. Gentamicin up to concentrations of $20 \mu \mathrm{g} / \mathrm{ml}$ had a negligible effect on the optical density in nutrient broth.

Viability curves

Cell viability was determined by a filtration technique. Aliquots of $5 \mathrm{ml}$ were filtered through polycarbonate filters and washed twice with $8 \mathrm{ml}$ of $3 \% \mathrm{NaCl}$ as above. Filters were then placed in sterile test tubes containing $2 \mathrm{ml}$ of nutrient broth. Sterile test tubes were vortex shaken to remove bacteria. Aliquots of the wash containing the bacteria were appropriately diluted in nutrient broth, then plated on nutrient agar for colony counts ${ }^{15}$.

Determination of minimal inhibitory concentration (MIC) values and minimal bactericidal concentrations (MBC)

MIC values in the test media were determined by inoculating approximately $1 \times 10^{6}$ organisms from an overnight culture into $3 \mathrm{ml}$ tubes containing 2-fold dilutions of gentamicin. The lowest concentration of antibiotic which yielded a clear tube at 18 hours was reported as the MIC. MBC values were determined by plating $0.1 \mathrm{ml}$ of the dilutions on nutrient agar. The lowest concentration which yielded no growth was designated as the MBC. Determinations were done in triplicate ${ }^{18)}$. 


\section{Results}

\section{Kinetics of Gentamicin Accumulation in the Presence of $\mathrm{NaCl}$}

Gentamicin accumulation in nutrient broth and nutrient broth with added $\mathrm{NaCl}$ is shown in Table 1. At low gentamicin concentrations, the presence of $\mathrm{NaCl}$ was associated with markedly decreased accumulation. At concentrations approaching the MIC or $\mathrm{MBC}$, a rapid upswing in the rate of gentamicin accumulation occurs.

Fig. 1 shows the time course of gentamicin accumulation in nutrient broth. Values are plotted as accumulation ( $\mu \mathrm{g} / \mathrm{mg}$ protein) divided by the medium concentration in order to present data over a wide range of concentrations (tissue-medium ratio in $\mathrm{ml}$ medium $/ \mathrm{mg}$ bacterial protein). There is little energy-dependent accumulation at $0.02 \mu \mathrm{g} / \mathrm{ml}$ (below the MIC). At $0.2 \mu \mathrm{g} / \mathrm{ml}$ the EDP-1 phase occurs from zero time until about 15 minutes followed by the more rapid EDP-2 phase. At concentrations above $0.2 \mu \mathrm{g} / \mathrm{ml}$ only one energy-dependent phase is observed, probably because EDP-1 occurs before the first ( 5 minutes) determination.

Accumulation in nutrient broth with added $\mathrm{NaCl}$ is shown in Fig. 2. At concentrations of $0.2 \mu \mathrm{g} / \mathrm{ml}$ and below (below the MIC under these conditions), there is little energy-dependent accumulation. At $2.0 \mu \mathrm{g} / \mathrm{ml}$, EDP-1 is present from about zero time to about 15 minutes. At concentrations above $2.0 \mu \mathrm{g} / \mathrm{ml}$, only the EDP-2 phase is apparent. Thus, at concentrations below the MIC, there is little energy-dependent accumulation. At high concentrations, only EDP-2 is apparent because of the short duration of EDP-1.

BRYAN has shown that the intracellular concentration of gentamicin may reach 150 200 times the medium concentration when accumulation is measured in nutrient broth ${ }^{3)}$. After 60 minutes at

Table 1. Gentamicin accumulation by E. coli.

\begin{tabular}{c|c|c}
\hline \multirow{2}{*}{$\begin{array}{c}\text { Medium } \\
\begin{array}{c}\text { concentration } \\
(\mu \mathrm{g} / \mathrm{ml})\end{array}\end{array}$} & $\begin{array}{c}\text { Accumulation at } 30 \mathrm{minutes} \\
(\mu \mathrm{g} / \mathrm{mg} \text { protein })\end{array}$ \\
\cline { 2 - 3 } & $\begin{array}{c}\text { Nutrient } \\
\text { broth }\end{array}$ & $\begin{array}{c}\text { Nutrient broth } \\
\text { with } 40 \mathrm{mM} \\
\text { increment } \\
\text { in NaCl } \\
\text { concentration }\end{array}$ \\
\hline 0.02 & 0.0015 & 0.00070 \\
0.2 & 0.275 & 0.0126 \\
2.0 & 12.5 & 1.21 \\
20.0 & 101.5 & 18.4 \\
200. & 114.5 & 99.2 \\
$\mathrm{MIC}(\mu \mathrm{g} / \mathrm{ml})$ & 0.052 & 2.3 \\
$\mathrm{MBC}(\mu \mathrm{g} / \mathrm{ml})$ & 0.104 & 3.3 \\
\hline
\end{tabular}

Bacteria were preincubated in nutrient broth or nutrient broth with $\mathrm{NaCl}$ for one hour prior to addition of gentamicin. Primary accumulation (value at zero time) was subtracted from the 30minute accumulation. Primary accumulation values were less than $3 \%$ of the 30 -minute accumulation values for all concentrations above $0.02 \mu \mathrm{g} / \mathrm{ml}$. Each value is the mean of three separate incubations.
Table 2. Accumulation of gentamicin assayed by centrifugation compared with assay by filtration.

A. Centrifugation

\begin{tabular}{l|c|c|c}
\hline $\begin{array}{c}\text { Medium } \\
\text { concentra- } \\
\text { tion }(\mu \mathrm{g} / \mathrm{ml})\end{array}$ & \multicolumn{2}{|c}{ Accumulation in $\mu \mathrm{g} / \mathrm{ml}$ protein } \\
\cline { 2 - 4 } & $4^{\circ} \mathrm{C}$ & $37^{\circ} \mathrm{C}$ & Net \\
\hline 0.02 & $0.036 \pm 0.005$ & $0.054 \pm 0.004$ & $0.018 \pm 0.006$ \\
2.0 & $3.57 \pm 0.86$ & $21.3 \pm 0.5$ & $17.7 \pm 1.2$ \\
\hline
\end{tabular}

B. Filtration

\begin{tabular}{l|c|c|c}
\hline $\begin{array}{c}\text { Medium } \\
\text { concentra- } \\
\text { tion }(\mu \mathrm{g} / \mathrm{ml})\end{array}$ & \multicolumn{3}{|c}{ Accumulation in $\mu \mathrm{g} / \mathrm{ml}$ protein } \\
\cline { 2 - 4 } & $0 \mathrm{~min}$. & $60 \mathrm{~min}$. & Net \\
\hline 0.02 & $\begin{array}{c}0.0002 \\
\pm 0.00006\end{array}$ & $\begin{array}{l}0.0063 \\
\pm 0.00055\end{array}$ & $\begin{array}{l}0.0063 \\
\pm 0.001\end{array}$ \\
2.0 & $0.066 \pm 0.016$ & $15.3 \pm 0.32$ & $15.2 \pm 0.96$
\end{tabular}

For accumulation using filtration, energy-dependent accumulation is the difference between the 60-minute accumulation and the zero time accumulation (Net). For accumulation using centrifugation, first phase (energy-independent) accumulation was determined by incubation at $4^{\circ} \mathrm{C}$. Energydependent accumulation is the difference between the 60 -minute accumulation at $37^{\circ} \mathrm{C}$ and $4^{\circ} \mathrm{C}$ (Net). Values are means \pm S.E. Each value is the mean of three separate incubations. 
Fig. 1. Accumulation of gentamicin in nutrient broth at $37^{\circ} \mathrm{C}$.

Gentamicin medium concentrations are indicated. Values denote accumulation in $\mu \mathrm{g} / \mathrm{mg}$ protein divided by medium concentration in $\mu \mathrm{g} / \mathrm{ml}$ (i.e. tissue-medium ratio expressed as $\mathrm{ml} \mathrm{medium} / \mathrm{mg}$ bacterial protein). Values are means \pm S.E. Each value is the mean of $3 \sim 9$ separate incubations.

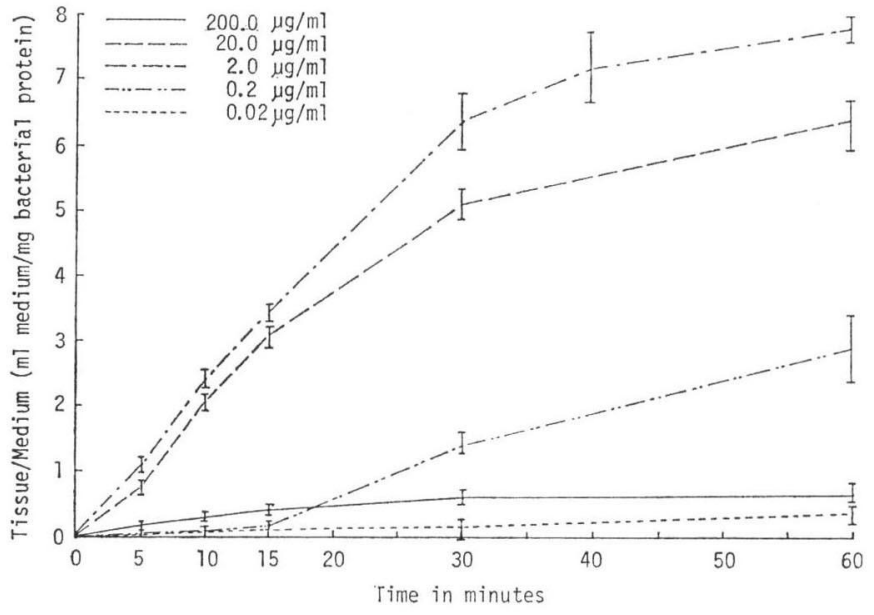

Fig. 2. Accumulation of gentamicin at $37^{\circ} \mathrm{C}$ in nutrient broth adjusted to $55 \mathrm{~mm}$ sodium concentration.

Gentamicin medium concentrations are indicated. Values are accumulation in $\mu \mathrm{g} / \mathrm{mg}$ bacterial protein divided by medium concentration in $\mu \mathrm{g} / \mathrm{ml}$ (i.e. tissue-medium ratio expressed as ml medium/ mg bacterial protein). Values are means \pm S.E. Each value is the mean of $3 \sim 9$ separate incubations.

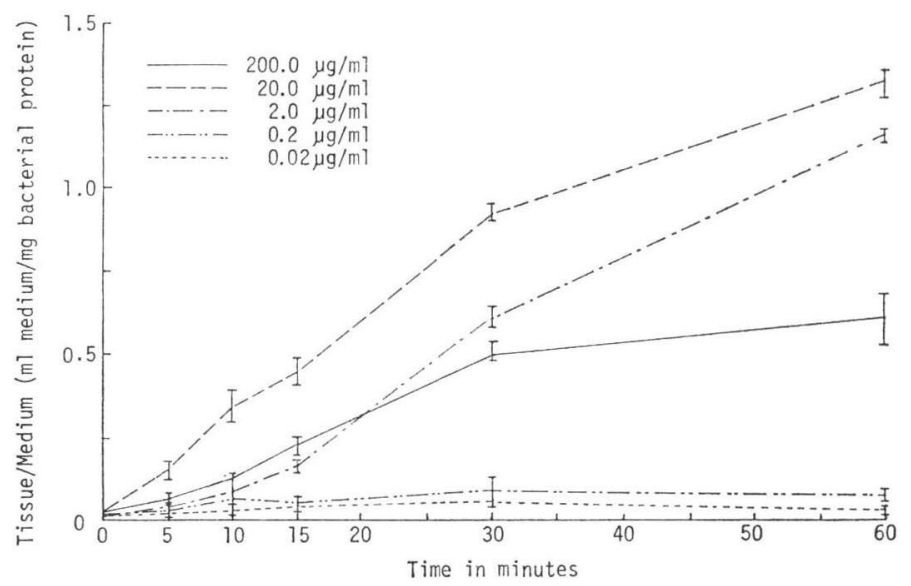

a medium concentration of $2.0 \mu \mathrm{g} / \mathrm{ml}$ in nutrient broth the ratio of intracellular to extracellular gentamicin was approximately 1,500 times. [This value assumes $2.7 \mu \mathrm{l}$ of cell water per mg dry weight of bacteria and $500 \mu \mathrm{g}$ protein per $\mathrm{mg}$ dry weight $\left.{ }^{3,16)}\right]$. Tissue medium ratios at 60 minutes in the presence of $\mathrm{NaCl}$ are reduced for all the concentrations tested. At $2.0 \mu \mathrm{g} / \mathrm{ml}$ the tissue-medium ratio (T/M) in the presence of $40 \mathrm{~mm}$ increment in $\mathrm{NaCl}$ concentration is $15 \%$ of the $\mathrm{T} / \mathrm{M}$ in nutrient broth alone (Figs. 1 and 2). The T/M falls at medium concentrations above $20 \mu \mathrm{g} / \mathrm{ml}$ indicating that some component of the energy-dependent accumulation is saturable. However, unlike a simple saturable transport system, accumulation at low concentrations (below the MIC under our conditions) yields low $\mathrm{T} / \mathrm{M}$ ratios. At low concentrations EDP-2 does not get underway. 
Fig. 3. Accumulation of gentamicin at $37^{\circ} \mathrm{C}$ in nutrient broth (sodium concentration $15 \mathrm{~mm}$ ), and in nutrient broth adjusted to sodium concentration $55 \mathrm{~mm}$.

Gentamicin concentrations are indicated. Values are tissue-medium ratio expressed as $\mathrm{ml}$ medium/mg bacterial protein.

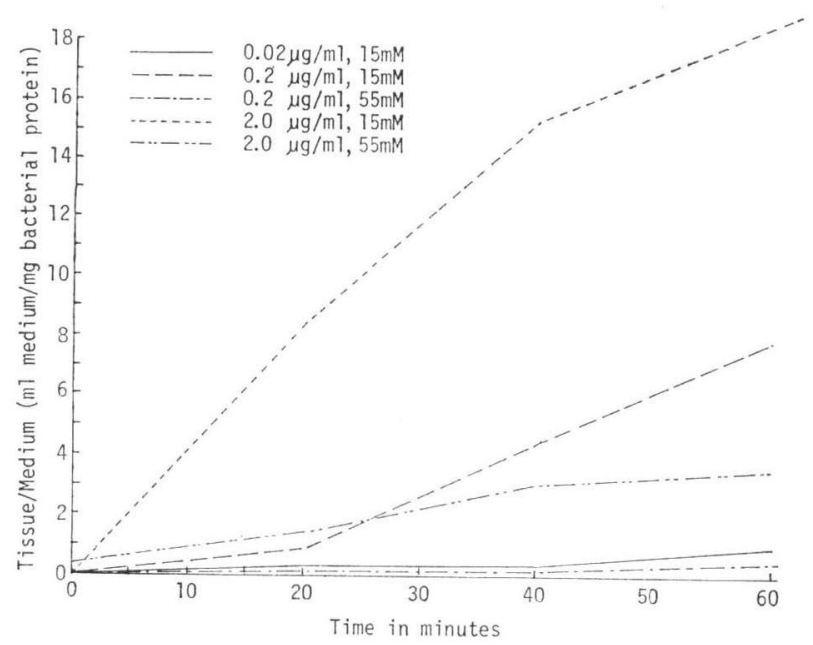

Fig. 4. Accumulation of gentamicin at $37^{\circ} \mathrm{C}$ in nutrient broth adjusted to sodium concentration $55 \mathrm{~mm}$ and $135 \mathrm{~mm}$.

Gentamicin concentrations are indicated. Values are tissue-medium ratio expressed as $\mathrm{ml}$ medium/mg bacterial protein. Accumulation at sodium concentration $135 \mathrm{~mm}$ was negligible (less than $0.05 \mathrm{ml}$ medium/mg bacterial protein) at gentamicin concentrations 0.2 and $0.02 \mu \mathrm{g} / \mathrm{ml}$ (not shown).

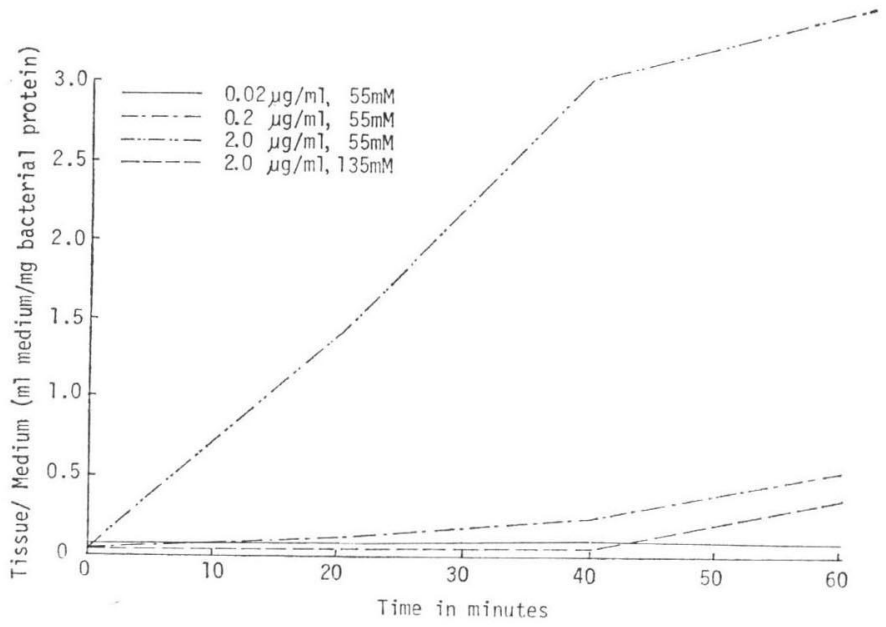

Fig. 5. Growth curves at $37^{\circ} \mathrm{C}$ in nutrient broth at three different sodium concentrations: A. nutrient broth (sodium concentration $15 \mathrm{~mm}$ ); $\mathrm{B}$. nutrient broth adjusted to sodium concentration $55 \mathrm{~mm}$; C. nutrient broth adjusted to sodium concentration $135 \mathrm{~mm}$.

Gentamicin concentrations are indicated. For each sodium concentration, control incubations containing no gentamicin showed linear logarithmic growth (not shown), and growth rate in the control incubations was identical for the three sodium concentrations tested.
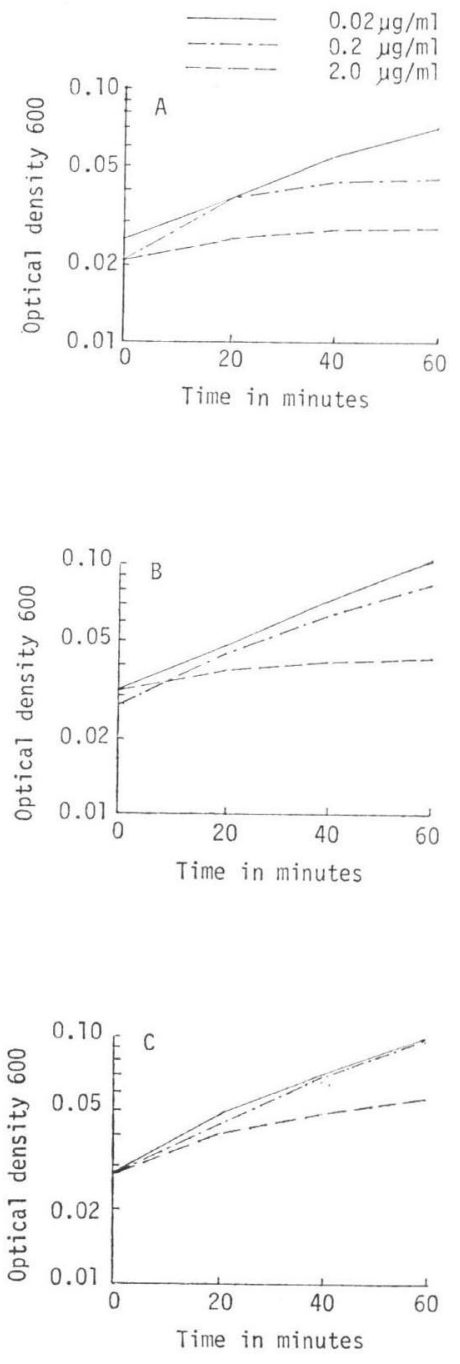
In order to confirm these results by an independent method, accumulation at 60 minutes was measured at gentamicin medium concentrations of 0.02 and $2.0 \mu \mathrm{g} / \mathrm{ml}$ by centrifugation under the same conditions as the above experiments (Table 2). Since zero time accumulation could not be assessed accurately with centrifugation, first phase (energy-independent binding) was estimated from flasks incubated at $4^{\circ} \mathrm{C}$. Energy-dependent accumulation was calculated by subtracting the accumulation at $4^{\circ} \mathrm{C}$ from the total accumulation at $37^{\circ} \mathrm{C}$ (net accumulation). For the concentrations tested (values above and below the MIC), there was good agreement between the two methods.

Gentamicin Accumulation in the Presence of $\mathrm{NaCl}$ : Relationship to Growth and Viability

In order to investigate the relationship between gentamicin accumulation, growth inhibition, and viability, aliquots for determination of gentamicin accumulation, optical density, and colony counts were simultaneously removed from incubation flasks. The time course of gentamicin accumulation in these experiments is shown in Figs. 3 and 4. These experiments were performed in the early logarithmic phase (growth from $\mathrm{OD}_{600} 0.06 \sim 0.130$ during the 60 minute incubation). Under these conditions, gentamicin accumulation was higher than observed in the earlier experiments (growth from $\mathrm{OD}_{800} 0.2 \sim 0.4$ ) for the same concentrations of gentamicin and $\mathrm{NaCl}$ (Figs. 1 and 2). Qualitatively, the kinetics are similar. The effect of increasing $\mathrm{NaCl}$ concentration (or decreasing gentamicin concentration) is a delay in the onset of EDP-2.

Simultaneous growth curves at the three different concentrations of $\mathrm{NaCl}$ are shown in Fig. 5 . The addition of $\mathrm{NaCl}$ to nutrient broth interferes substantially with the antimicrobial activity of gentamicin under these experimental conditions. From comparison with Figs. 3 and 4, it is apparent that growth inhibition is roughly coincident with the onset of EDP-2. Fig. 6 shows accumulation, growth, and viability at a gentamicin concentration of $0.2 \mu \mathrm{g} / \mathrm{ml}$. At $\mathrm{NaCl}$ concentration $15 \mathrm{~mm}$, accumulation, growth inhibition, and loss of viability are apparent by twenty minutes, while at $\mathrm{NaCl}$ concentration of $55 \mathrm{~mm}$ accumulation begins to pick up at about forty minutes, and growth inhibition and loss of viability are not apparent until forty to sixty minutes of incubation. At $\mathrm{NaCl}$ concentrations of $120 \mathrm{~mm}$, there is negligible accumulation, and cell growth and viability are not appreciably different from controls without antibiotic. The relationship between accumulation and viability after sixty

Fig. 6. Effect of sodium concentration on gentamicin accumulation, growth, and cell viability at gentamicin concentration $0.2 \mu \mathrm{g} / \mathrm{ml}$.

Aliquots for determination of gentamicin accumulation, bacterial growth, and viability were similtaneously removed from incubation flasks. Values are means \pm S.E. Each value is the mean of 5 separate incubations.
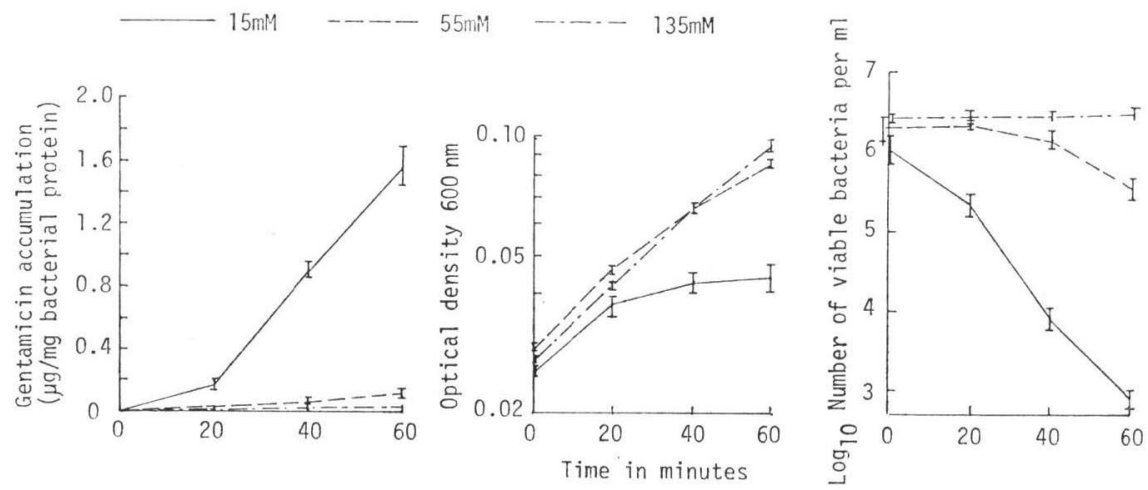
minutes of incubation for different concentrations of gentamicin and $\mathrm{NaCl}$ in the medium is shown in Fig. 7. When the medium contains various concentrations of $\mathrm{NaCl}$, antimicrobial activity is not determined by the gentamicin medium concentration, however, there is a close correlation between antimicrobial activity and gentamicin accumulation. The correlation between accumulation and cell viability at sixty minutes, determined by the Spearman rank test, was $\mathrm{r}_{\mathrm{s}}=-0.956$, corresponding to $p<$ $0.001^{7)}$. Similar correlation held between accumulation and cell growth (not shown), $\mathrm{r}_{\mathrm{s}}=$ $-0.950, p<0.001$. These plots constructed at twenty and forty minutes incubation gave similar results.

\section{Gentamicin Accumulation at Lowered $\mathrm{pH}$}

The effect of acid $\mathrm{pH}$ was investigated by the addition of $1 \mathrm{~N} \mathrm{HCl}$ to nutrient broth after autoclaving ( $\mathrm{pH} \mathrm{5.5)} \mathrm{(Fig.} \mathrm{8).} \mathrm{At} 20 \mu \mathrm{g} / \mathrm{ml}$, accumulation, growth inhibition and loss of viability are apparent by 20 minutes, while at $2.0 \mu \mathrm{g} / \mathrm{ml}$ accumulation begins to pick up between $20 \sim 40$ minutes, and growth inhibition and loss of viability are not apparent until 40 60 minutes of incubation. In other experiments (not shown) at gentamicin concentrations of $0.2 \mu \mathrm{g}$ or below, there was no effect of gentamicin.

Fig. 8. Gentamicin accumulation, bacterial growth, and cell viability in nutrient broth adjusted to $\mathrm{pH} 5.5$ at $37^{\circ} \mathrm{C}$

Gentamicin concentrations are indicated. Aliquots for determination of gentamicin accumulation, bacterial growth, and viability were simultaneously removed from incubation flasks. Values are means \pm S.E. Each value is the mean of three separate incubations.
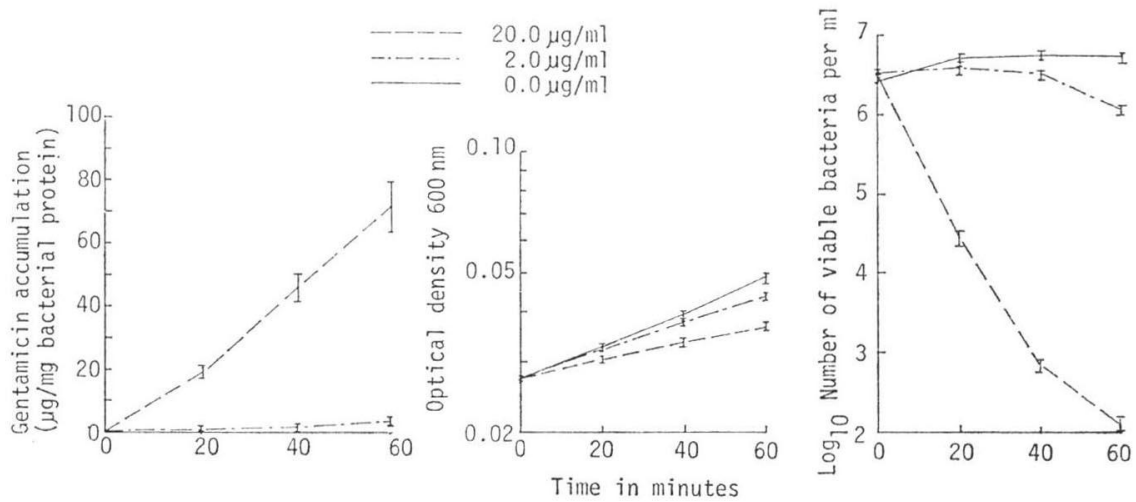


\section{Discussion}

The kinetics of gentamicin accumulation in nutrient broth which we observed are similar to the kinetics described by BRYAN and his co-workers ${ }^{3,5)}$. At concentrations in the neighborhood of the minimal inhibitory concentration of the organism in the test medium, we observed three phases of accumulation: the rapid energy-independent phase, and two phases of energy-dependent accumulation, equivalent to the energy-dependent phase 1 (EDP-1) and energy-dependent phase 2 (EDP-2) described by BRYAN ${ }^{5)}$. At concentrations well below the MIC of the organism, there was relatively little accumulation over a one hour incubation period, and no EDP-2 phase was observed. At concentrations well above the MIC, two energy-dependent phases are not apparent, presumably because EDP-1 occurs too rapidly to be appreciated by five minutes. At some medium concentrations above the MIC, the intracellular concentration of gentamicin reaches 1,500 times the extracellular concentration. At very high medium concentrations the ratio is lower, indicating saturation of some component of the system.

The observation that at low concentrations, tissue-medium ratios are low, indicates that gentamicin transport is not a "well-behaved" transport system with simple transport kinetics. This is demonstrated by the multiphasic accumulation kinetics and the fact that EDP-2 is not seen at concentrations below those inhibiting growth ${ }^{3}$. This observation was confirmed by centrifugation, eliminating any possibility that cell washing removes accumulated gentamicin at low concentrations.

BRYAN and co-workers have shown that divalent cations antagonize bacterial transport across the cell membrane and that monovalent cations are also effective, but at higher concentrations ${ }^{5)}$. Cations antagonize transport of streptomycin in ribosomally resistant strains of E. coli and presumably interfere with EDP-1. Based on the results of elegant studies with mutants of E. coli, BRYAN and VAN DEN ELZEN have postulated that EDP-1 represents aminoglycoside transport across the cell membrane by a low affinity membrane energization complex, possibly involving respiratory quinones. Cations might antagonize this transport by competing with the antibiotic for binding to this membrane component. The interaction of membrane-bound aminoglycosides with ribosomal binding sites would then initiate the more rapid EDP-2 phase $^{5}$.

In our experiments the addition of sodium chloride to nutrient broth results in reduce energydependent accumulation for all gentamicin concentrations studied. This is most prominent at lower gentamicin concentrations and appears to be associated with a delay in the time of onset of EDP-2; however, when EDP-2 does occur, its rate is less rapid than the rate observed in controls at the same gentamicin concentration.

It is well known that sodium chloride (or ionic strength) affects the antimicrobial activity of aminoglycoside antibiotics ${ }^{14)}$, and that this may have important clinical implications ${ }^{13,17)}$. BEGGS and ANDREWs found that monovalent and divalent cations inhibit dihydrostreptomycin accumulation by $\mathrm{Myco}-$ bacterium smegmatis, and correlated this effect with inhibition of antimicrobial activity ${ }^{1,2)}$. We have shown that under our experimental conditions there is a good correlation between the magnitude of energy-dependent gentamicin accumulation and antimicrobial activity. Accumulation of approximately $0.01 \mu \mathrm{g}$ gentamicin sulfate per $\mathrm{mg}$ of bacterial protein was associated with the onset of loss of viability and growth inhibition in experiments with sodium chloride. This magnitude of accumulation corresponds to approximately $4 \times 10^{3}$ molecules of gentamicin per bacterium assuming molecular weight of gentamicin of $723 \mathrm{~g} / \mathrm{M}$ and $5 \times 10^{-10} \mu \mathrm{g}$ protein per bacterium ${ }^{16)}$. Further accumulation was associated with a greater degree of growth inhibition and loss of viability.

Since gentamicin acts by causing misreading of synthetic RNA messengers, which effect is concentration-dependent in vitro ${ }^{8)}$, it is likely that there is a minimum amount of gentamicin accumulation which is necessary for antimicrobial activity. We emphasize, however, that we have only demonstrated a correlation between accumulation and antimicrobial activity, and not a cause and effect relationship. It is conceivable that some accumulation is the result of earlier irreversible intracellular changes.

When $\mathrm{pH}$ is lowered to 5.5 (an increment of $3 \mathrm{~mm}$ in $\mathrm{HCl}$ concentration) in nutrient broth, there is a marked reduction in accumulation, suggesting that hydrogen ion is more potent than sodium in inhibiting accumulation in our system. Even for a given amount of accumulation, antimicrobial ac- 
tivity was apparently less than in experiments at varying sodium chloride and gentamicin concentrations. This may reflect differences in intracellular metabolism in acid $\mathrm{pH}$ (growth was slower), or alteration in the intracellular distribution or state of the accumulated gentamicin.

The relationship of aminoglycoside accumulation to antimicrobial activity has important clinical consequences. Altered accumulation provides a rationale for the relative resistance of anaerobes to aminoglycosides ${ }^{6)}$, and may explain observed differences in the antimicrobial activity of different aminoglycosides ${ }^{11}$. Reduced accumulation of aminoglycosides may be of clinical significance in patients with urinary tract infections where cations and acid $\mathrm{pH}$ limit antibiotic efficacy ${ }^{12)}$. Anaerobic conditions also reduce gentamicin accumulation, and it is possible that reduced accumulation due to acid $\mathrm{pH}$ and anaerobic conditions may protect organisms in abscesses.

\section{Acknowledgement}

We wish to thank Mr. Robert E. Lopez, Drs. Manuel Guzman, Thomas O'Brien, and Peter Goldman for their encouragement and support, and Ms. DIANE KILDAY for secretarial assistance.

This study was supported in part by National Institutes of Health National Research Service Award $1 \mathrm{~F}$ 32 NS $05770-01$ from the NINCDS, and in part from funds provided by a Special Award from the BurroughsWellcome Fund.

\section{References}

1) BegGs, W. H. \& F. A. Andrews: Inhibition of dihydrostreptomycin binding to Mycobacterium smegmatis by monovalent and divalent cation salts. Antimicr. Agents \& Chemoth. 9: 393 396, 1976

2) BeGgs, W. H. \& F. A. Andrews: Role of ionic strength in salt antagonism of aminoglycoside action on Escherichia coli and Pseudomonas aeruginosa. J. Infect. Dis. 134: 500 504, 1976

3) Bryan, L. E. \& H. M. Van Den Elzen: Gentamicin accumulation by sensitive strains of Escherichia coli and Pseudomonas aeruginosa. J. Antibiotics 28: 696 703, 1975

4) Bryan, L. E. \& H. M. VAN Den Elzen: Streptomycin accumulation in susceptible and resistant strains of Escherichia coli and Pseudomonas aeruginosa. Antimic. Agents \& Chemoth. 9: 928 938, 1976

5) Bryan, L. E. \& H. M. VAN Den Elzen: Effects of membrane-energy mutations and cations on streptomycin and gentamicin accumulation by bacteria: a model for entry of streptomycin and gentamicin in susceptible and resistant bacteria. Antimicr. Agents \& Chemoth. 12: 163 177, 1977

6) Bryan, L. E.; S. K. Kowand \& H. M. Van Den Elzen: Mechanism of aminoglycoside antibiotic resistance in anaerobic bacteria: Clostridium perfringens and Bacteroides fragilis. Antimicr. Agents \& Chemoth. 15: 7 13, 1979

7) Colquhoun, D.: Lectures on biostatistics. Clarendon Press, Oxford, 1971

8) DAvies, J. \& B. Davis: Misreading of ribonucleic acid code words induced by aminoglycoside antibiotics. J. Biol. Chem. 243: 3312 3316, 1968

9) Kobayashi, Y. \& D. V. Maudsley: Practical aspects of double isotope counting. pp. 76 82. In E. D. Bransome, Jr. (ed.). The Current Status of Liquid Scintillation Counting. Grune and Stratton, Inc., New York, 1969

10) LAYNE, E.: Spectrophotometric and turbidometric methods for measuring proteins. pp. 447 450. In S. P. Colowick \& N. O. Kaplan (eds.). Methods in enzymology. Vol. 3. Academic Press, Inc., New York, 1957

11) Lee, B. K.; R. G. Condon, H. Munayyer \& M. J. Weinstein: Uptake of (methyl ${ }^{14} \mathrm{C}$ )-sisomicin and (methyl- ${ }^{14} \mathrm{C}$ )-gemtamicin into bacterial cells. J. Antibiotics 31: 141 146, 1978

12) Minuth, J. N.; D. M. MusheR \& S. B. Thorsteinsson: Inhibition of the antimicrobial activity of gentamycin by urine. J. Infect. Dis. 133: 14 20, 1976

13) Medeiros, A. A.; T. F. O'Brien, W. E. C. Wacker \& N. F. Yulug: Effect of salt concentration on the apparent in-vitro susceptibility of Pseudomonas and other Gram-negative bacilli to gentamicin. J. Infect. Dis. 124 S: S 59 S 64, 1971

14) Rubensis, M.; V. M. KoziJ \& G. G. Jackson: Laboratory studies on gentamicin. Antimicr. Agents \& Chemoth. $-1963: 153 \sim 156,1964$

15) Shah, P. M.; G. Heetderks \& W. Stille: Bactericidal activity of amikacin and gentamicin. Chemotherapy $23: 260 \sim 266,1977$ 
16) Sistrom, W. R.: Microbial Life. Holt, Rinehart \& Winston, New York, 1962

17) Washington, J. A.; R. J. Snyder, P. C. Kohner, C. G. Wiltse, D. M. Ilstrup \& J. T. McCall: Effect of cation content of agar on the activity of gentamicin, tobramycin, and amikacin against Pseudomonas aeruginosa. J. Infect. Dis. 137: 103 110, 1978

18) Wolf, P. L.; B. Russell \& A. Shimoda: Practical clinical microbiology and mycology: Techniques and interpretations. Wiley, New York, 1975 